肝再生に括けるアルドラーゼ遺伝子発現の変化

\begin{tabular}{|c|c|c|c|}
\hline 村 光明 & 尾崎 & 岩太 & 堺 \\
\hline 城 圭一郎 & 向井 & 常博 & 堀 \\
\hline
\end{tabular}

はじめに：アルドラーゼアインザイム（EC 4.1. 2.13）は六炭糖のフルクトース 1,6 二リン酸を三炭 糖のジヒドロキシアセトンリン酸とクリリルアルデヒ ド三リン酸に開裂・縮合する解糖系の醭素であり分子 量16万ダルトンで四量体を形成する。現在，三つのタ イプが知られており，それらは筋型 (A 型), 肝型 (B 型) および脳型 (C 型) と呼ばれている.これら三種類 の醭素は組織特異的 (歲器特異的) 発現を示し, 発生・ 分化に伴って発現の型転換を行い，肝では胎生初期の 分化以前には C 型が主で, 胎児では $\mathrm{A}$ 型, 肝の成熟と ともに B 型が出現することが知られている゙。 また癌 化にともない, 特に肝䯈癌で B 型から A 型に移行す る例が知られており, 癌化之遦伝子発現の異常との関 連において興味がすたれる. 今回, 部分切除後肝再生 におけるアルドラーゼ遺层子の mRNAの発現を経時 的に検討した結果, 興味ある結果を得たので報告する。

方法：ウイスター系雄性ラット(体重200g)を2/3部 分肝切除し経時的に再生肝を摘出し Hot Phenol 法で total RNA を摘出し oligo-dT カラムで polyA+RNA を分画しノーザン法によりフルドラーゼ $\mathrm{A} ・ \mathrm{~B} ・ \mathrm{C} ， \boldsymbol{T}$ ルブミン, $\beta$-フクチンの mRNA の発現を検討した. ア ルドラーゼ A の mRNA には, 骨格筋で発現している $\mathrm{M}$ 型と胎児肝・脳などで発現している $\mathrm{AH}$ 型が存在す る2,3)が, アルドラーゼ A の M 型の cDNA プローブを 用いて $\mathrm{S}_{1}$ ヌレアーゼプロテクション法を行った。

次に，4 日目・7日目の再生肝をこラゲナーゼかん 流後に, percoll による密度勾配遠心により肝実質細胞 を分離し，フルドラーゼ A の mRNA の発現を検討し た. 正常肝之部分肝切除後 4 日目の再生肝の核を回収 し, Huang らの方法4により in vitro 核転写を行い, あらかじめアルドラーゼ $\mathrm{A} ・ \mathrm{~B}$, フルブミン cDNAを ドットスポットしたニトロセルロースフィルターに, in vitro 核転写で得た riboprobe を加え $60^{\circ} \mathrm{C} て ゙ 72$ 時間 ハイブリダイゼーションを行らことによりフルドラー

*佐賀医科大学内科

** 同 生化学

〈受付日63年 1 月13日 $>$
ゼ A・B の核での転写効率を検討した。

結果：部分切除後再生肝ではフルドラーゼ B の発 現は経時的に不変だった. 一方, アルドラーゼ A の発 現は再生 2 日目から増加し 4 日目にピークを示し再生 14日です増加していた(Fig. 1). フルドラーゼCの発 琴は同定されなかった。 $\beta$ アクチンの発現は再生 3 日 から増加し 4 日にピークを示したが14日には正常レべ ルに復し肝再生時の細胞増殖と一致した発現の变化を 示した，肝再生時に増加したアルドラーゼAの mRNA の型を調べるために M 型の cDNA プローブ を用いて $\mathrm{S}_{1}$ ヌクレアーゼプロテクション法を行った 結果, アルドラーゼ A の AH 型の mRNAの発現が増 加していた(Fig. 2). また，percoll 分画後の肝実質細 胞での発現を検討した結果, 再生肝の肝実質細胞でア ルドラーゼAの発現が増加していることが明らかと なった。この発現の増加が核での転写効率によるのか

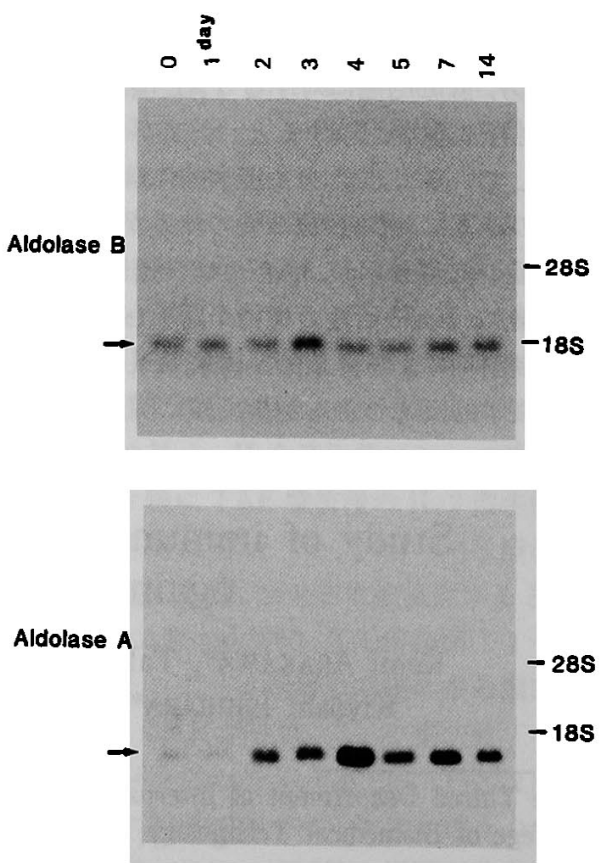

Fig. 1 Expression of Aldolase A and B mRNA in liver regeneration 


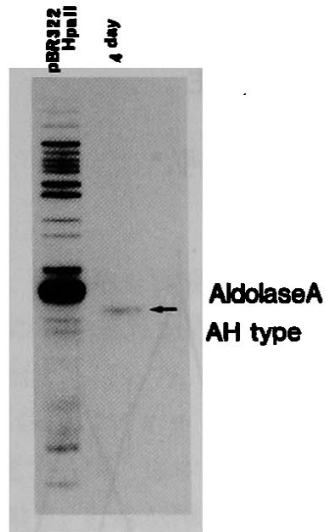

Fig. $2 S_{1}$ nuclease analysis of rat Aldolase $A$ mRNA in liver regeneration

どうかを調べるため正常肝と部分切除後 4 日目の再生 肝の核を回収し in vitro 核転写を行った。その結果， アルドラーゼ $\mathrm{A} ・ \mathrm{~B}$, アルブミンの転写効率は, 正常肝 と再生肝 4 日目で著明な変化はみられなかった。

考案：アルドラーゼは組織特異的な分布を示し発 生・分化や癌化に伴ってその発現パターンは特有の変 化を示す5).組織特異的に発現するメカニズムや発生・ 分化に伴らアイソザイム間のスイッチング機構を明ら かにすることは癌化の解明にも重要と思われる。

部分切除後の肝再生においててルドラーゼ・ピルビ ン酸キナーゼ・へキソキナーゼなどのアイソザイムが 一過性に胎児性パターンをとることは蛋白レベルでは 以前から知られていだ). 肝再生時に肝実質細胞の醅 素偏倚が生じ，この変化は細胞分裂が生じる以前にみ られることが多い：この酸素偏倚は部分切除後に生じ る肝再生の調節因子（インスリン・グルカゴン・EGF などの液性因子や，コラーゲン・神経因子・肝細胞膜 調節因子(10)など)によって誘導される現象と思われる。
肝再生の調節因子が残余肝に作用しアルドラーゼ遺伝 子の発現す変化すると考えられる。 ノーザン法の結果 から再生肝ではフルドラーゼ A の発現が増大してい たが，正常肝と再生 4 日目の in vitro 核転写にはアル ドラーゼAの転写効率に著明な変化はみられず転写 後のアルドラーゼ Am RNA の安定化によっていると 思われた．解糖系醭素の一つであるビルビン酸キナー ぜも再生肝飞扔いて成体型の L 型が減少し胎児型の $\mathrm{M}$ 型が増加すると報告されている7)。またビルビン酸 キナーゼの mRNAの発現はグルカゴンやC-AMPの 投与により転写後にも調節される8). 再生時に胎児型 フインザイムを産生する細胞として網内系細胞とする 説9!，一過性に変化した肝実質細胞とする説7がある が, mRNAの発現の結果から再生時の肝実質細胞が 産生することが明らかとなった。現在，初代培盖肝細 胞系や in situ hybridizationによる検討を行ってい る.

索引用語：再生肝, アルドラーゼ連伝子

文 献：1) Horecker BL: In the Enzymes, vol. 7, Edited by Boyer PD, Academic Press, New York, 1972, p213-258 2) Mukai T, et al: J Biol Chem 261 : 3347-3354, 1986 3) Joh K, et al: J Mol Biol 190 : 401-410, 1986 4) Marzluff WF, et al: Transcription and translation, Edited by Hames BD, IRL Press, Oxford, England, 1984, p89-129 5) Edwards YH, et al: In: Isozymes, vol. 1, Edited by Rattazzi MC, Alan R. Liss Inc, New York, 1977, p19 -78 6) Berges J: FEBS Letters 48 : 76-79, 1974 7) Bonney RJ, et al: Biochem J $136: 947,1973$ 8) Vaulont S, et al: J Biol Chem 261: 7621-7625, 1986 9) Weber A, et al: Biochem Biophys Res Commun $86: 6-13,1979$ 10) Nakamura $T$, et al: Proc Natl Acad Sci USA 80 : 7229-7233, 1983

\title{
Change of aldolase gene expression during liver regeneration
}

\author{
Mitsuaki MotomURA, Iwata OzakI, Takahiro SAKaI*, Keiichiro JoH,
} Tsunehiro MUKal and Katsuji HoRI ${ }^{* *}$

\footnotetext{
* Department of Internal Medicine, Saga Medical School (Saga)

** Department of Biochemistry, Saga Medical School (Saga)
} 